\title{
THINKING ABOUT POLITICS
}

\section{Andre Modigliani and William A. Gamson}

There are distinctive modes of thinking about politics, three of which are discussed here. A mode consists of a characteristic domain of relevance, filing system, and grammar of beliefs. A person relying on Mode A treats politics as an extension of interpersonal experience. A person relying on Mode $B$ organizes political thinking around a set of salient group identifications. A person relying on Mode $\mathrm{C}$ views public objects in terms of their consequences for collective goods. The three modes are illustrated by applying them to concrete issues in a hypothetical manner: Vietnam, bussing, and attitudes toward presidential candidates. The concept of surrogate attitudes is developed and various implications of the theoretical argument are discussed.

Shortly after the collapse of the Army of South Vietnam in April 1975, an Associated Press reporter did a series of interviews with Vietnam veterans in a small midwestern town. One of the interviewees had been permanently crippled by a mortar round near Da Nang. The report of the interview quotes him as follows:

Lately there have been a lot of people saying we should go back over there. Well, by God, if they want to go back over there, give 'em a rifle and send 'em back over. The only ones I've heard who want to go are too old to fight. Either that or they don't have any sons or grandsons. In seven years there, we were supposed to be training them and we did most of the fighting and it didn't help. It didn't do any good so if we go back over again and try to retrain them and try to help them, I still don't think it's going to make any difference. (pause) We lost a lot of guys over there. I lost a lot of friends. I think it's a waste. (The reporter asks him who is to blame for the lost use of his legs.) I just don't know. I don't think we should have been over there in the first place, but yet I was sent over there to do a job and I went and I came back wounded and hurt. ... No, I guess I can't blame anybody. ${ }^{1}$

Andre Modigliani and William A. Gamson, Department of Sociology, The University of Michigan. 
We are concerned in this paper with how people respond to public objects. Among the objects that are of particular interest to us are those conventionally labeled "political." By objects, we mean people, policies, institutions, and events. By public, we mean those objects encountered, directly or indirectly, through a public medium such as newspapers or television. The fact that there is an accounting of these objects in the mass media makes them public even if the final channel of communication to some individuals is interpersonal. There are distinctive modes or characteristic ways of thinking about political objects (Lane, 1973). Such modes of thinking are similar to what Converse (1964) refers to as "belief systems." 2 We prefer the idea of mode of thinking, because we wish to emphasize an active mind, one which is in the process of thinking about public objects. We are concerned with the operation of the black box - the box that connects a political stimulus with some attitudinal or behavioral response. We are not satisfied with reducing the complex body of thought in the mind of the Vietnam veteran quoted above to some simple valence code such as pro or anti, hawk or dove. We seek a way of characterizing the mode of thought that he employs in an effort to capture something more of the richness and complexity contained in his answers.

We will argue here that there are a limited number of general modes of thinking about politics. We will single out three, but without claiming at this point that they are necessarily exhaustive. Some of us use all three modes; others may use only one or two. No mode is better than any other: the distinctions we will be making among the modes are not invidious ones. We do not see them as hierarchical or as stages of development, and warn the reader against treating our modes as "higher" or "lower" ways of thinking. We suspect that most people rely on a predominant mode. However, it is not our intention or desire to classify individuals through our distinctions but to understand different ways of thinking about politics.

\section{THE NATURE OF MODES OF THINKING ABOUT PUBLIC OBJECTS: THE MODEL}

In describing the three modes, we operate with a general model of how people think about public objects. The model is described as follows. A continual stream of public objects passes before us. We select from this stream certain ones to attend to; these enter our domain of relevance. We are able to assimilate only certain parts of this domain because of the nature of our filing system; some things we are unable to file or assimilate. Finally we develop an orientation toward the object; we apply to it a grammar of beliefs. If this process is completed, then 


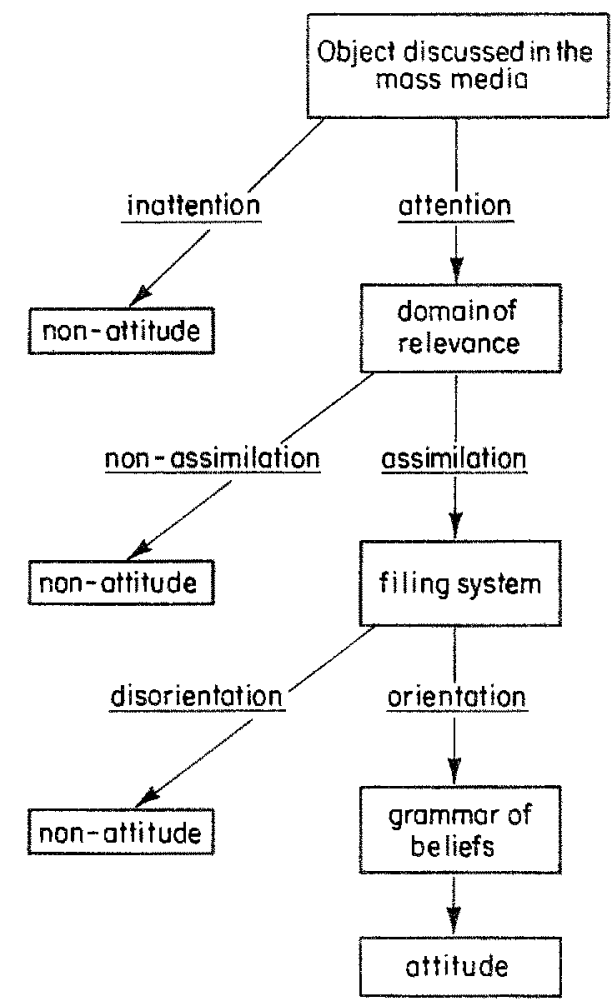

Figure 1. The Nature of a Mode.

the public object is imbued with meaning and valence, and we can say that we have an attitude toward it. This model is described in more detail below and is summarized in Figure 1.

\section{Step One: Attention}

As objects pass before us, some are of interest to us and some are not. Of course, this is a manipulated process since it is difficult to avoid attending to certain objects whether we are interested in them or not. It is not the social process by which certain things are called to one's attention that is of concern here but, rather, the social-psychological process by which a person focuses attention on those things that he cares about. ${ }^{3}$ We assume that everybody has a domain of relevance determined by their personal goals or concerns. When they employ a 
particular mode of thinking about public objects, they are guided by a general question or inclusion rule. Each of the three modes has a characteristic inclusion rule to answer the question: Is this something that concerns me? This rule selects what is included in the domain. We can expect much variation in the content of what is included among individuals and this variation will exist within modes as well as among them. Some people are concerned quite a bit about a Presidential election or peace in the Middle East and include a great many political objects in their domain of relevance. Others, for whatever reasons, don't have many political objects in their domain. Our primary concern here is not with individual variations but with variations among modes. The first question we ask for a given mode is: What is the inclusion rule for its domain of relevance?

\section{Step Two: Assimilation}

Once something is in our domain of relevance, we assimilate it by placing it in one or more categories of our filing system. This concept is similar to what Rosenberg and Abelson (1960) call the "cognitive file." We locate the object by deciding what previously filed objects it is like. We may locate it in several different categories simultaneously. Each mode has a characteristic basis of classification for its filing system. The categories of the filing system are keyed to this basis. Again we can expect much variation in the categories that individuals use, even among those employing the same mode. Some sections of an individual's file may be tightly packed with entries, while other sections are nearly empty; parts of one's filing system will be finely differentiated while other parts will be quite gross. No doubt some individuals have mostly empty drawers while others have files as stuffed as the FBI's. Our primary concern is not with individual variations but with variations among modes. The second question we ask for a given mode is: What attributes are used to distinguish among and to categorize public objects? What is the basis of classification?

\section{Step Three: Orientation}

Once an object is filed, we apply to it a set of beliefs relating the relevant file categories to other idea elements. These beliefs may be both normative and empirical. We call the set of such beliefs a grammar. ${ }^{4}$ Orientation is a process of applying a grammar of beliefs to an object that has been assimilated into categories in a filing system. We assume that each individual has some grammar of beliefs. One is able to deal with an object because it is like other things that one has thought 
about in the past. The rules or beliefs that govern one's orientation to these already considered objects are applied to the new object. Each individual's grammar of beliefs has a particular content. Some individuals have a relatively powerful grammar that enables them to draw a wide array of implications; in effect, they are able to bring to bear a rich armature derived from much past reading, conversation, and thought. Others have relatively few idea elements connected with most of their categories. Again, our concern is not with individual differences but with the characteristic grammars of each of the three modes. The third question we ask for a given mode is: What is the structure of its grammar of beliefs?

A mode, then, involves three structural elements: a domain of relevance, a filing system, and a grammar of beliefs. These elements combine to form a characteristic general structure. Since a mode exists in a single mind, we assume that the three structural elements articulate with each other to provide an integrated and coherent way of thinking about public objects. We do not expect the different parts of a mode to be independent but to be functionally interrelated.

Before we attempt to give concrete form to this highly abstract and general model, we would like to note an important assumption here. As Figure 1 indicates, only if all of the above steps are completed is it meaningful to talk about someone as having a full-fledged attitude toward an object. The process of producing an attitude may abort at any of three points. First, a person may be inattentive. Second, he may not be able to assimilate the object because his filing system lacks the appropriate categories or is insufficiently differentiated. Third, when he applies his grammar of beliefs for orientation, it may contain many contradictions and inconsistencies, resulting in confusion and disorientation. A nonattitude does not mean that a person will produce no response. If asked a question about the object by a survey interviewer, a person will give some appropriate answer, but it will have little or nothing to do with the object in question. Converse (1970) suggests that many survey questions elicit such nonattitudes from respondents who "with no real attitudes on the matter in question... [feel] for some reason ... obliged to try a response to the item.... When attitudes are asked for in such a [survey research] setting, people are remarkably obliging."

\section{TYPES OF MODES}

To prevent the discussion of the modes from becoming excessively abstract, we will employ a device. We will suppose some individuals, each of whom relies exclusively on a single mode in responding to two 
concrete issues: the end of the war in Vietnam and court-ordered bussing to achieve racial integration of schools. This concretizing device runs the danger that the reader will mistakenly think of this typology as a way of distinguishing individuals rather than modes of thinking, but it simplifies the presentation considerably. We will proceed by sketching each mode as a whole before discussing its parts more systematically. The person relying on Mode A treats politics as an extension of interpersonal experience. He has learned certain rules of thumb for dealing with the social world he encounters in his immediate, everyday life, and he treats public objects by extending these rules to those objects that seem to affect him in concrete ways. Sometimes he has difficulty finding applicable rules and can't easily render such objects meaningful. Some of his attitudes may be mediated by surrogates: friends whose judgment he respects or public figures who seem to reflect his code of personal conduct. The person relying on Mode B organizes his political beliefs around a set of salient group identifications. He recognizes that political events affect different groups in different ways. His world contains a "we" and "they" or a series of such. Like our first person, he may also have difficulty determining how some public events will affect his concerns. His attitudes may be mediated by surrogates: friends who share his solidarities or public figures who seem to speak for groups with whom he identifies.

The person relying on Mode $\mathrm{C}$ views public objects in terms of their consequences for given states of collectivities in which she participates. ${ }^{5}$ These system states are states of the social world that she would like to see achieved or maintained. They may range from abstract states such as liberty and equality to concrete ones such as clean water and safe streets. In this mode, a person is responding in terms of the effects of public objects on collective goods-goods which are available to all members of the collectivity if they are produced at all. ${ }^{6} \mathrm{We}$ acknowledge that in many cases her desire that such goods be produced may mask a solidarity group or concrete personal interest, but if she is using Mode C, the system states have acquired functional autonomy as a way of thinking about politics. She reacts to public objects by how they affect these collective goods without direct reference to subgroup or personal interests that may ultimately support her beliefs. Like persons using other modes, she may need guidance on how given objects affect her concerns. Some of her attitudes may be mediated by surrogates: friends who share her desired system states or public figures who seem to share her goals for the system. Having sketched each mode briefly, we will now present each one in detail. We will do this by applying the modes to concrete hypothetical examples on Vietnam and bussing. To 
avoid associating a given mode with any particular valence or "side" on these issues, we will present two contrasting examples of each mode in operation on each side of the two issues.

\section{Mode A: Personal Experience}

People using this mode attend to politics if political events impinge on their lives in a concrete way. We include here effects on family and friends. Those who are attempting to lead lives of quiet dignity under difficult circumstances may have quite a limited domain of relevance when it comes to politics. Much of what is covered on the front page of a daily newspaper or on the television news is likely to seem very remote indeed, without any obvious relevance. The pell-mell American exit from Vietnam is a good example of an event that is unlikely to be in the domain of relevance of most people operating in this mode. During the period in which more than half a million Americans were stationed in Vietnam, some might very well have a friend, relative, or a friend's son in danger, and the war might enter their domain. By 1975, the war would have lost its salience for most such people. For the purposes of our example, we will assume an individual for whom the war is still salient. Perhaps the person is a disabled veteran of the war, such as the man quoted at the beginning of this paper. Perhaps she is the mother of one of the 56,000 Americans killed there. Connected with such an important personal experience, the Vietnam war is likely to remain in the domain of relevance even though the events leading to the personal consequences occurred in the past rather than the present.

The filing system of someone relying on this mode is based on types of interpersonal situations. We assume that there will be great variety among individuals in the content of their categories, and hence we are unable to say as much about them in general as we would like. We hope that there are certain widely used categories that can be discovered empirically. For example, a person may typically classify his interactions into those with friends and intimates, those with associates, those with subordinates or superordinates, and those with people who are basically hostile. He may classify his interactions between those that have pleasant personal consequences and those that don't. In any event, we assume that he has some classification of types of interpersonal situations that enables him to frame the activities in which he engages in his daily life. To assimilate a political object, he must determine in which of his files it belongs. His classification need not have such properties as mutual exclusiveness or exhaustiveness. Hence, he may decide that a political event is like several types of 
interpersonal situations he knows, or like none at all. With the freedom that our hypothetical case gives us, we will assume an individual who has a category of "fighting" to which he can assimilate the Vietnam War. The American exit from Vietnam is the end of a fight. We still don't know what his attitude will be until we know what he thinks about fights. To complicate matters further, "fighting" may not be the only relevant category. Vietnam involvement might also be classified as a job or task voluntarily undertaken.

The grammar of beliefs of someone using this mode consists of beliefs about personal conduct in interpersonal situations. Some of these beliefs may be prescriptive: for example, "Do unto others as you would have them do unto you," or "Look before you leap." Others may be empirical generalizations: for example, "Blue-eyed people are untrustworthy," or "People are more likely to keep promises if they make them publicly." Individuals operating in this mode have certain favorites which they have inherited from parents or learned in other ways. They use them to apply lessons about interpersonal situations to politics. To know how a person operating in this mode will respond to the American withdrawal from Vietnam, we need to know the content of his grammar. We suggested earlier that one applicable part of the grammar is that dealing with fights. There are potentially many different beliefs that might be part of such a person's grammar. For example, he might give high priority to the belief, "Don't get involved in other people's quarrels" and "Turn the other cheek." Conversely, or simultaneously, he might give priority to "Everyone should help a friend in need," and "Only a coward runs from a fight." If the war also happens to be categorized as a job undertaken voluntarily, then such beliefs as "Fish or cut bait," and "Anything worth doing is worth doing well" may be applied also.

The grammar of a mode is its heart-it determines much of the meaning and valence that an individual will ultimately attach to those political objects that she attends to and can assimilate. Most grammars contain potential contradictions. This may create no problem with many objects since the contradictory elements may not be simultaneously activated. If they are, the individual will get confused and fluctuate in a volatile fashion as first one rule and then its opposite seems salient. Frequently, she will be able to keep them sufficiently compartmentalized so that basically consistent ones will be operative and she will produce a relatively stable attitude toward the object under most circumstances. Predicting what a real individual thinks about Vietnam or any other issue requires that we know not only the mode being used but something of the content. This is an empirical task. It is important to know the mode for interpreting what a person is saying. 
We provide two vignettes of individuals using a personal experience mode to illustrate how such a mode might be applied to Vietnam:

Person \#1: I've been following the war news because I had a son over there who was killed about three years ago. I never did understand what he died for-you know, what we were fighting for. But it doesn't seem to me that it could have been worth the lives of all those American boys. Mind you, I hoped the South Vietnamese could do the job on their own, but if they can't, that's their problem and not ours. As for those arguments about fighting for our country and for justice, they just don't make much sense to me. Where is the justice in having my son killed and my friends' sons killed? What good does it do for the country? It's just nonsense and I'm glad we're finally out of it.

Person \#2: I don't know whether we should have been in there or not but I do know this: Nothing good comes from running away from a fight. If people see that you are weak-willed and unwilling to follow through on something you started, they will take advantage of you. Maybe that's not the best place to stand up and fight for what we believe in, but sooner or later, we are going to have to show that we can't be pushed around. World War II proved that. Millions of people were killed because we didn't stop Hitler early when we had our best chance. I fought in that war and I lost a lot of friends. I know a lot of people say we shouldn't have gotten involved in Vietnam and perhaps they're right. But once we got involved, it was our fight too and a lot of people were depending on us. We shouldn't have let those people down.

Apply the same mode to bussing to achieve racial integration. For some, it is a remote issue, happening in other communities to other people. In communities where the black population is negligible, for example, most inhabitants are unlikely to perceive any dixect, concrete effects on their personal lives. Events occurring around this social controversy would not fall in the domain of relevance of people using this mode. If our hypothetical person happens to be a resident of Roxbury or South Boston, it is extremely likely to be in her domain of relevance. If she does not herself have children who would be bussed, she is almost certain to have friends or neighbors who are intensely concerned. In any event, we will assume a person with a child who, under a court ordered integration plan, would be bussed to a school in a neighboring community. There are many ways in which this complex stimulus event could be filed. For our example, we will assume that the person has a category of events involuntarily affecting family members and intimates, including a subcategory of potentially dangerous events. We will further assume that "protect your loved ones from danger" occupies a central place in her grammar of beliefs. Such a person might express her attitude as follows: 
Person \#3: I don't care what they do about bussing anywhere else in the country - they can do what they like, it's no skin off my back. I have nothing against black people. I'm all for civil rights. I believe they have rights and are entitled to demand certain things. I think they deserve the best education they can get. I'm for those things. But I don't want my kid bussed somewhere where there might be danger or at the very least disruption in the way the school operates. So I'm against the bussing of my son and of the sons and daughters of others who feel as I do. As for the more general, philosophical arguments on either side of the issue-the supreme court decisions and the rights of this person and that person-I don't follow those things. They don't interest me.

Or, alternatively, if it is classified as less dangerous:

Person \#4: I don't really see that it makes that much difference. Bussing itself doesn't hurt anybody. I took busses to school and it's nothing to make a fuss about. I want my kid to get a good education. It's not clear that the school he goes to now is all that great. It's all the controversy and fuss that is making for problems. If people would just quiet down and get on with the job of education, I think it would be better for everybody.

\section{Mode B: Solidarity}

People using this mode attend to politics if political events affect groups with which they identify. There are two important variants of this mode. In one, the individual has a single overriding group identification. This is especially likely to be true of minority group members such as blacks or Jews, but might include workers or other bases of solidarity besides ethnicity. In the second variant, the individual has a series of group identifications of varying levels of intensity. For most people in either variant, much of what is covered on the front page of a daily newspaper or on the television news is not likely to have much obvious relevance for their identification groups. ${ }^{7}$ In our example, we will assume that the person relying on this mode is black and has a strong black identification. There is no strong reason to expect the withdrawal from Vietnam to be in her domain of relevance. Although an argument can be made that a disproportionate cost of the war fell upon black people, there is little evidence to suggest that most black people saw the war as differentially affecting their group. To make this issue part of her domain of relevance, we will assume that she also has a strong identification with the solidary group "Americans."

The filing system of a person relying on this mode is made up of groups, some her own, some neutral, and sorne hostile. The filing system not only contains categories but cross-references based on relationships among groups. Thus, she can assimilate not only events that 
affect her own groups but those that affect other groups in her files. The act of assimilating a public object involves classifying it with other objects that affect group interests in a similar way. For a person relying exclusively on this mode, every public object that is assimilated is a solidarity issue. The grammar of beliefs of someone using this mode consists of beliefs about intergroup relations. These beliefs govern the obligations toward one's fellow members and toward various categories of outsiders. Examples from the grammar of beliefs include such things as: "If we don't hang together, then surely we shall all hang separately"; "May my country always be right, but my country right or wrong"; "Now is the time for all good men to come to the aid of the party"; "Don't wash dirty linen in public"; "Don't bad mouth a brother to an outsider"; "Blood is thicker than water"; "My enemy"s enemy is my friend, my friend's enemy is my enemy"; and "In a fight between a group member and an outsider, always back the group member."

As always, we need to know more about the content of the filing system and grammar of beliefs before we can predict how a person using this mode thinks about the Vietnam withdrawal. An example of such a person using this mode might run as follows:

Person \#5: Myself, I'm glad it's over. I never did understand what we were after over there. There didn't seem to be anything to gain. And I don't have any quarrel with those Viet Cong either. They don't have anything that's ours as far as I can see. We never should have become their enemy. (Pause) A lot of people were killed-and a lot of them black, too. I'm only sorry we didn't get out earlier. As for those arguments about patriotism and fighting for freedom, I don't know what they are talking about. Our freedom, such as it is, was never threatened and there is nothing patriotic about supporting an unnecessary war.

Or, alternatively:

Person \#6: I'm opposed to the withdrawal. How can anyone support it? Look, this is our country, right? Well, I don't like to see our country get licked. I'm proud of it and I want to see it be a winner. I don't really know how we got involved over there but we are involved now and nothing can change that. In fact, we're involved so much that I just can't see the percentage in ending up losers. We'll just look really bad. That to me overrides all those arguments about loss of life and little to gain; or those technicalities about a declaration of war. It comes down to this: I'd like my country to be number one, always.

Bussing is likely to be a highly salient issue for a black person who is using this mode. Although his attitude may be quite complex, he is almost certain to be aware that the issue involves black-white relations. Hence, if his black identification is central, this issue will be in his 
domain of relevance. As for filing the issue, there are many cues that those who are hostile to his group are opposed to court ordered bussing. There is no real need for him to get into the content of the issue to assimilate it into his filing system. The issue has achieved a symbolic status which makes the assimilation process quite easy and direct. A person using this mode might not really care about the issues involved in bussing per se and might be more concerned, for example, with quality education for his children. However, once the bussing issue becomes a black-white solidarity issue, he will respond in terms of group loyalty. Such a person, responding in a solidarity mode, might say something like the following:

Person \#7: Looking at it narrowly, I can see that, in the short run, there isn't much in it for me or my people. The schools are bad over there and our kids could get hurt if there is trouble. But I have to take a broader perspective. Those white folks that don't want my children in their schools are the enemy of black people. We have been fighting against them for 400 years. We're not going to stop now. I know that the black groups in town are for bussing here and elsewhere and I am too. As for arguments about neighborhood schools or even equal opportunity, I don't put much stock in them, I mean neighborhood schools are nice, but there are more important things. As I see it, it's us against them and we"ve got to stand together now just as we have before.

Or, alternatively:

Person \#8: I'm against bussing. It separates our children and mingles them with whites at the wrong time. This is a time when we need to stand together and demand our due. This bussing program is no big gift. They act as if they're doing us a favor. How can it be a favor to offer someone what they' re entitled to? Their real attitude is: 'We don't want you,' So why should we associate with them? It's bad for us, bad for our pride. And just because a lot of whites are against it, doesn't mean we have to be for it. We can have our own program.

\section{Mode C: Ideology}

People using this mode attend to politics if political events affect collective goods that are important to them. Depending on how broad or narrow these collective goods are, such people may have large or small domains of relevance. If the only collective good a person cared about was, for example, a clean and healthful environment, she would likely find most of what is covered on the front page of a daily newspaper or on the television news quite irrelevant. For our example, we will assume a person relying on this mode who is concerned about several 
states of American society that she believes are closely interdependent: freedom, preservation of the "American way of life," and national security defined in terms of military strength. Public objects are in her domain of relevance if they affect these collective goods. The Vietnam War is likely to be in the domain of relevance of such a person, although it may have arrived there quite late. Public figures have told her, in effect, that the war effort is helpful to the collective goods that she cares about.

The filing system of someone relying on this mode is based on common or similar effects. To assimilate a political object, people using this mode classify it with other objects that are linked in the same instrumental way to their desired system states. The exact content of the filing system of a person using this mode, as with other modes, is an empirical question. In our hypothetical example, we can assume that "war" is a category that is related to such collective goods as "freedom," "the American way of life," and "national security." The grammar of beliefs of someone using this mode consists of beliefs relating classes of political objects to collective goods. These beliefs take categories such as "war" or "the government in Washington" and relate them to other political objects that are directly or indirectly linked to collective goods. We will appropriate the term "ideology" to refer to a grammar of beliefs of this type. Example of elements in an ideology include: "That government is best that governs least"; "Power corrupts and absolute power corrupts absolutely"; "Individual initiative produces a society with the greatest good for the greatest number"; "The Democratic Party tends to favor a more active use of governmental power to solve domestic problems"; "Never get involved in a land war in Asia"; "Communism is a threat to freedom"; and "Being strong militarily is the surest way to preserve the security of the country." An ideology may have contradictory elements just as the other grammars may. We do not assume that this mode is necessarily more internally consistent. As we use the term here, ideologies may range from sophisticated to primitive. Without knowing the content of the grammar, we could not know how a person using this mode would respond to the American withdrawal from Vietnam. It could be viewed as the liquidation of a costly blunder that was weakening the country and giving aid and comfort to its enemies. He could respond with relief. Or the withdrawal might be seen as an act of betrayal of important collective goods that were being defended by the American effort in Vietnam. An example of a Vietnam attitude of a person using this mode might run as follows:

Person \#9: The way we are running out of Vietnam worries me a lot. Communism stands against our way of life. Freedom, democracy, and reli- 
gion all disappear under Communism. Not that we're perfect or anything, but they trample on these things. Right now the Communists have a lot of Asia. They are pushing for still more. If we let them take South Vietnam, they'll just keep right on going. I believe they are a threat to our way of life and I believe we should have stayed there to fight them. Those arguments about too many American lives being lost and about too much domestic unrest don't move me. War is terrible, but the preservation of our way of life is worth the price. As for unrest, there are always people who don't understand what is st stake in a war and some of them are troublemakers. But they are no big problem; they have a perfect right to protest as long as they do it peacefully.

Or, alternatively:

Person \#10: I think we should have withdrawn from Vietnam four years ago. In fact, we never should have sent our boys there in the first place. I'm not for Communism or anything-I know they may be a threat to us. But the fact remains that the war was never declared. Congress never decided that we should get into this War, the way the constitution says it's supposed to happen. Johnson and a few Congressmen just fooled us into thinking they had the right to send our boys over there. But they had no right and that's what always bothered me. That's why the American people never supported this war and why we're better off out of it.

To apply the same mode to bussing, we will assume that the person relying on this mode has in his filing system a category about "exercise of governmental authority." Some exercises involve positive acts that help to preserve the states of the system that he is concerned about. Other exercises are seen as unwanted intrusions of the government, examples of it doing things it has no business doing. To understand what he thinks about bussing we would have to know more about the content of his grammar of beliefs. An example of a bussing attitude of a person using this mode might run as follows:

Person \#11: I really don't think it's necessary. Mostly it's been the govermment using force to get people to do things they don't want to do. Now if these people had done something wrong, well then I'd see it. But they are just ordinary people trying to run their lives and get their kids through their schools. These people are really upset. I've seen the faces on some of them and they are really worked up. Well, I'm against the government forcing people against their will unless it's absolutely necessary-like to protect the public safety or something like that. Here, it's a matter of Blacks getting an equal education. Well, I think they're entitled to that but not through the use of force. There are other ways such as improving their schools or integrating neighborhoods.

Or, alternatively: 


\begin{tabular}{l|l|l|l} 
Mode & $\begin{array}{l}\text { Domain of } \\
\text { Relevance } \\
\text { (inclusion } \\
\text { rule) }\end{array}$ & $\begin{array}{c}\text { Filing } \\
\text { System } \\
\text { (Basis of } \\
\text { classification) }\end{array}$ & $\begin{array}{l}\text { Grammar of } \\
\text { Beliefs } \\
\text { (Structure) }\end{array}$ \\
\hline $\begin{array}{l}\text { Experience } \\
\text { B. Solidarity }\end{array}$ & $\begin{array}{l}\text { Objects that } \\
\text { affect personal } \\
\text { life }\end{array}$ & $\begin{array}{l}\text { Objects that } \\
\text { affect identifi- } \\
\text { interpersonal } \\
\text { situations }\end{array}$ & $\begin{array}{l}\text { Classes of } \\
\text { groups } \\
\text { personoups about } \\
\text { in interpersonal } \\
\text { situations }\end{array}$ \\
\hline C.Ideology & $\begin{array}{l}\text { Objects that } \\
\text { affect } \\
\text { collective } \\
\text { goods }\end{array}$ & $\begin{array}{l}\text { Beliefs about } \\
\text { intergroup } \\
\text { relotions }\end{array}$ \\
\hline
\end{tabular}

Figure 2. Summary of the Three Modes.

Person \#12: I think you've got to comply with court orders. The order was based on Supreme Court decisions. Whether you' re for bussing or against it, you have to allow it to take place. The law is the law and without laws, where would we be? Personally, I don't care either way about bussing-I rode a bus to school when I was a kid and I never liked it much. But people who are resisting bussing are wrong-they're resisting the Constitution. It's like George Wallace standing in the doorway of that University. Same thing, only it's happening in the North. I know that some people are going to be hurt or unhappy but they don't have the right to disobey the law.

Figure 2 summarizes our initial statement of the three modes of thinking about politics. In it, we cross the three modes with the three structural elements: domain of relevance, filing system, and grammar of beliefs.

\section{SURROGATE ATTITUDES}

Not everyone is interested in politics. For many people it is a bore or a confusing scene. They find it necessary to deal with political objects from time to time because things that they are concerned about are affected. However, they are willing to utilize significant short cuts for thinking about politics when these are conveniently available. This is also true for the most sophisticated observer of the political scene. Even such a person isn't likely to have a fully developed, well-thoughtthrough position on every political issue or a knowledgable judgment about every public man or woman. The major short cut that we use is to 
rely heavily on the judgment of others. Essentially, everybody's attitudes are mediated, in varying degrees, by trust and personal influence. We will call attitudes arrived at in this fashion surrogate attitudes. Instead of being mediated by applying a grammar of beliefs, surrogate attitudes are mediated by other people. Such other people may be those one knows directly and interacts with personally, or those known to one through the mass media, i.e., public figures. Candidates for political office are a particularly interesting class of political figures; leaders of social movements are another.

Support for a political figure is a form of political trust. It is the analogy at a public level to personal influence at the level of face-toface interaction. The process is one of relying to some degree on the judgment of others. This does not mean that one necessarily suspends one's own independent judgment, although this occurs often enough. We frequently suspend our judgment on an issue because we trust other people's judgment for one reason or another. The extent to which an attitude is mediated by trust or mediated through a grammar of beliefs affects the anchoring of an attitude. By an anchored attitude, we mean one reflecting a stable attribute of a person rather than an offhand response to a fleeting stimulus. Well-anchored attitudes will be reliably produced by a variety of different stimulus events. In this sense, we distinguish surrogate attitudes sharply from nonattitudes. We regard them as sufficiently anchored to be worthy of study as a class in their own right. It is a hypothesis of our argument that attitudes which are mediated by both surrogates and by a grammar of beliefs will be especially well anchored. They will be less susceptible to change over time, buttressed as they are in this double fashion. The question of the relative stability of attitudes that are only mediated by surrogates remains open. We reserve the term full-fledged attitude to describe an attitude mediated by both in mutually consistent fashion. Figure 3 expresses this modification of our original model, introducing the surrogate as an alternative mediator to produce an attitude while bypassing the grammar of beliefs. We emphasize again that both pathways to an attitude may be utilized by an individual simultaneously, in varying degrees.

The reasons that we use for relying on one or another person's judgment are important and vary by mode. We argue that there is a different basis underlying trust in political figures in each mode. For the personal experience mode, one trusts public figures on the basis of their code of personal conduct. A person relying on this mode asks whether the figure has qualities of personal character or personality that bode well for his or her conduct in office. The character traits 


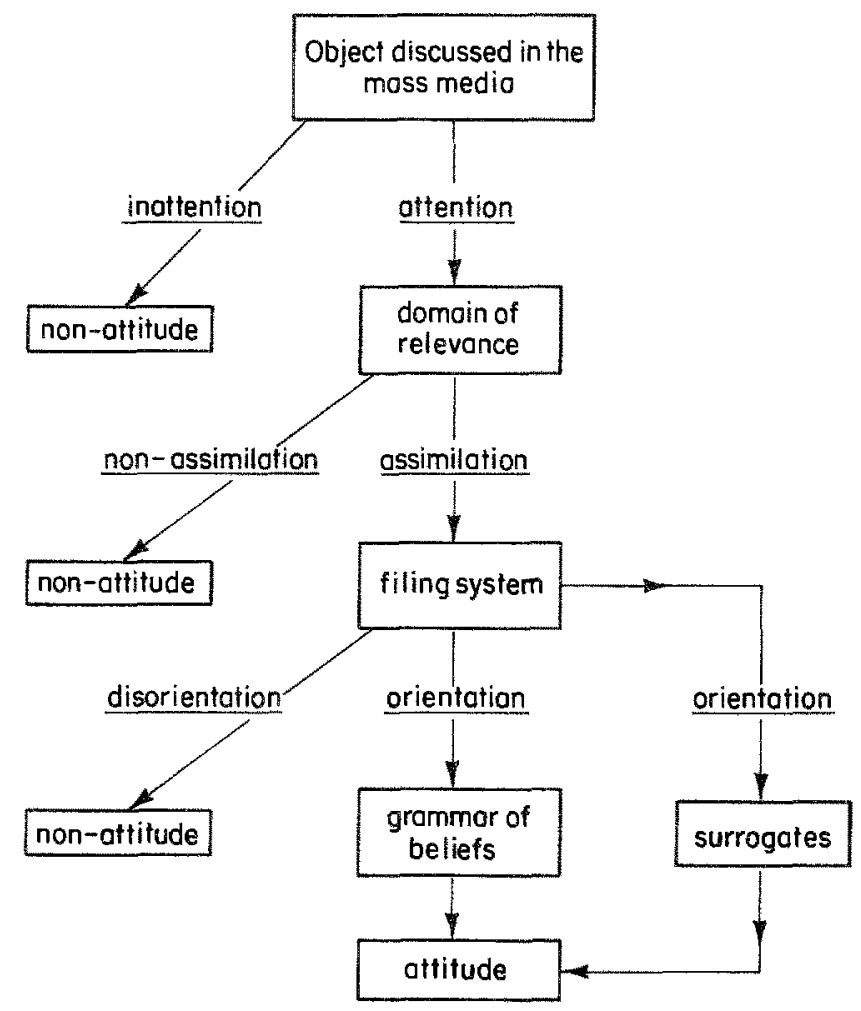

Figure 3. The Expanded Model.

emphasized will vary from individual to individual but among Americans they are likely to include such things as honesty, decency, experience, trustworthiness, courage, fortitude, decisiveness and the like. A person operating in the solidarity mode trusts political figures on the basis of the solidarities they exhibit. One trusts those who share the same solidarities and show that they are willing to act on the basis of those solidarities. A person operating in an ideological mode trusts those who give indications that they want and are able to achieve desired collective goods. One is likely to be concerned about the programs and policies that a political figure advocates and pursues. With all modes, such judgments about political figures may be well supported or based on flimsy and unreliable information. To illustrate how the modes might be applied to political figures, we will imagine a group of people during the 1976 presidential primary season, expressing their reasons for preferring a particular candidate.

For the personal experience mode: 
Person \#13: Well, I prefer Jimmy Carter, It seems to me that he's a pretty open person, ready to listen to new ideas. He isn't crazy and likely to stir things up too much but he might be able to get us out of some of the mess we're in. He doesn't seem reckless. I understand he conducted himself pretty well as governor. He made a lot of friends down there and not too many enemies that I can see. He sounds like he's ready to try some fresh ideas and I don't think that things are going so well that we can afford to stand pat with the answers we've been using.

Or, alternatively:

Person \#14: My candidate is President Ford. You know exactly where he stands. He is trying his best to do a difficult job. The man doesn't have any real malice in him. Things don't seem to be going so badly that we need to break in somebody new.

For the solidarity mode:

Person \#15: I'm for Senator Jackson. I'm Jewish and one of the things I'm really concerned about is the survival of Israel. Senator Jackson is the only person who really seems to care about the issue. The others make a lot of the right noises but you can tell they don't really care one way or the other. They're just being political. But Jackson has shown in a lot of ways that he's really committed. The fact that he's not Jewish is all the better because he doesn't have to bend over backwards so that people won't think he's being biased.

Or, alternatively:

Person \#16: I support George Wallace. He's the only one that's really willing to tell them where to get off. I know those kinds of people-the ones who call him a "racist" and call those of us who support him "racists." They're the ones who live out in the suburbs and never pay the consequences of anything that happens. Or they're pointy-headed intellectuals who think they're so smart but then mess everything up with their fancy, University developed programs for which we bear the social costs. Wallace has got the interest of the ordinary man at heart and the more they look down on him and the more they make fun of what he says, and how he says it, the more I'm for him.

For the ideological mode:

Person \#17: I prefer Governor Reagan. He has a vision of what America should be. He hasn't lost direction as a lot of others have and still maintains a sense of what is really important for the country. He recognizes that excessive concern with one's image in the world is sentimental nonsense that doesn't really protect our national interest. He wants to leave people free to pursue their private concerns without too much government meddling. This is how we got to be the richest and most powerful country in the world. $\mathrm{He}$ 


\begin{tabular}{|c|c|c|c|c|}
\hline Mode & $\begin{array}{l}\text { Domain of } \\
\text { Relevance } \\
\text { (inclusion } \\
\text { rule) }\end{array}$ & $\begin{array}{c}\text { Filing } \\
\text { System } \\
\text { (Bosis of } \\
\text { classification) }\end{array}$ & $\begin{array}{l}\text { Grammar of } \\
\text { Beliefs } \\
\text { (Structure) }\end{array}$ & $\begin{array}{l}\text { Surrogates } \\
\text { (Basis for } \\
\text { Selection) }\end{array}$ \\
\hline $\begin{array}{l}\text { A. Personal } \\
\text { Experience }\end{array}$ & $\begin{array}{l}\text { Objects that } \\
\text { affect personal } \\
\text { life }\end{array}$ & $\begin{array}{l}\text { Classes of } \\
\text { interpersonal } \\
\text { situations }\end{array}$ & $\begin{array}{l}\text { Beliefs obout } \\
\text { personal conduct } \\
\text { in interpersonal } \\
\text { situations }\end{array}$ & $\begin{array}{l}\text { Personal } \\
\text { charocter }\end{array}$ \\
\hline B. Solidarity & $\begin{array}{l}\text { Objects that } \\
\text { affect identifi- } \\
\text { cotion groups. }\end{array}$ & $\begin{array}{l}\text { Classes of } \\
\text { groups }\end{array}$ & $\begin{array}{l}\text { Beliefs about } \\
\text { intergroup } \\
\text { relations }\end{array}$ & $\begin{array}{l}\text { Shared } \\
\text { solidarities }\end{array}$ \\
\hline C. ideology & $\begin{array}{l}\text { Objects that } \\
\text { offect } \\
\text { collective } \\
\text { goods }\end{array}$ & $\begin{array}{l}\text { Classes of } \\
\text { affects on } \\
\text { collective } \\
\text { goods }\end{array}$ & $\begin{array}{l}\text { Beliefs relating } \\
\text { classes of } \\
\text { objects to } \\
\text { collective goods. }\end{array}$ & $\begin{array}{l}\text { Shared } \\
\text { beliefs about } \\
\text { collective } \\
\text { goods }\end{array}$ \\
\hline
\end{tabular}

Figure 4. Expanded Summary of the Three Modes.

showed as Governor that he had enough courage to push unpopular measures through that were necessary but difficult to take in the short run-for example, cutting people off the public payroll.

Or, alternatively:

Person \#18: I'm for Mo Udall. He has a long established record in Congress on a lot of issues and he has shown himself to be a consistent liberal, or progressive, or whatever you want to call it. The fact is that he's been on the right side most of the time and sometimes before it became terribly popular to be on that side. Furthermore, he played a leadership role in Congress in lining up others on a lot of important issues-for example, on protecting the environment.

Figure 4 expands the summary of the modes in Figure 2 to include the different bases for choosing surrogates in mediating political attitudes.

\section{IMPLICATIONS}

We have sketched three modes that we believe are the most widely used by Americans in thinking about political objects. We claim no originality for the division into modes based on concrete personal experience, solidarities, and ideology. On the contrary, we think that much of the literature on political attitudes and voting of the last 30 years has emphasized one or another of these modes. However, there 
are a number of implications of treating the modes as we have here that are not obvious.

\section{Modes as Vectors}

We do not assume that only some small elite has collective goods that they care about. On the contrary, we assume that everyone has states of the system that concern them, but not everyone uses these collective goods as a basis for thinking about politics. By the same token, almost everyone has some group identifications, but not everyone uses these identifications as a basis for responding to politics. Finally, we all have our ways of dealing with interpersonal interaction without necessarily using our beliefs in this area as a basis for approaching most political events. We personally use all three modes on different occasions although we rely most heavily on the ideological mode. We know that when we read of Senator Proxmire ridiculing studies of social psychologists, we feel the tug of solidarity outweighing the arguments on the merits or demerits of the peer review system in science. We would not testify critically before Senator Proxmire about the study of a fellow social scientist even though we might have severe reservations about his or her work. Such criticisms, in our solidarity beliefs, should be reserved for internal "scientific" forums rather than "political" forums. Senator Proxmire is not a member of our guild. Similarly, when we read about Senator Kennedy's behavior at Chappaquidick, we are tempted to make judgments about his personal character rather than attending to his political acts and the political policies with which he is identified. Most of the time, however, we rely on an ideological mode.

To treat modes as an attribute of an individual, it is most useful to think of them as elements in a probability vector. We assume that an individual has a weight attached to each mode reflecting a probability of use. We allow for the possibility that some people will use only one mode; thus they would have an entry of 1.0 for this mode while the other two would carry a weight of 0 . It is reasonable to hypothesize that most people have a favored mode. Indeed, if one lacks any ideology for dealing with political objects, such a mode is simply unavailable. The person must then choose from the remaining two. Some individuals may have no group identifications that are sufficiently salient to be applicable very often. If they also have no ideology, they will simply rely on the personal experience mode in thinking about politics. Methods used to discover the modes people use must employ techniques that have a possibility of evoking all three modes. The objective of measurement is not to classify people into modes but to discover the 
values of their mode vector. This task will be simplified considerably if it turns out that a given issue or class of objects is stably associated with a single mode for an individual. If this turns out to be true, then people may be characterized as relying on a single mode with respect to a specified class of objects.

\section{The Category of "Politics"}

We are particularly interested in a subcategory of public events that we consider "political." This is a meaningful category for us but we recognize that it is not shared by many citizens. Recently, some newspapers reported a visit to the United States of a love child of a World War II romance between an American naval attaché and a Soviet actress. For us, this is not a political event; it does not affect any of the collective goods which are mediated by the polity. However, we are ready to grant that others see this as an event of considerable interest on which they have very definite opinions. Newspapers such as the $\mathrm{Na}$ tional Enquirer devote much of their coverage to what are, for us, "nonevents." In the end, we claim the privilege that any investigator has of choosing to study responses to public objects that interest us, but we do not judge others for finding different events more interesting. We have a nonattitude toward many events that they may have thought about at some length. In asking about the political events that interest us, we do not assume that they employ the same category of "political" objects that we employ.

\section{Some Methodological Implications}

We have argued that to understand and interpret what a person thinks about a political object, one must understand the mode of thinking he is using. One needs to gather information about the person depending on the mode. For example, information on the collective goods that a person desires is only relevant for understanding his attitudes if he happens to be employing an ideological mode. Information on solidarities or codes of personal conduct are, likewise, only relevant under certain specific conditions. Anyone who has had interviewing experience in conducting sample surveys realizes that the survey instrument is an imperfect one, generating a good deal of noise along with the information it invokes. Our argument helps to identify some of the sources of noise. We would hypothesize, for example, that interviewer effects are most pronounced when a question invokes a solidarity mode for the respondent. At such a point, the interviewer's solidarity group 
attributes become quite salient. If the interviewer appears to be a member of a group regarded as hostile, the respondent is likely to be quite careful in revealing her true attitude. If she is responding in a different mode, however, the interviewer's attributes are less likely to be relevant. Similarly, different question wordings on the same subject matter can invoke different modes from a respondent. The resultant answers might be substantially different if this occurs, especially if the questions concern a topic about which the respondent has thought very little.

Our analysis also has implications for response set. If an individual has a nonattitude toward a particular political object, she is likely to find agreement the simplest way of changing the subject. Disagreement is more likely to lead to further questions while agreement is a device for creating closure on the present subject. If the question form does not allow for simple agreement (for example, a forced choice item), the respondent may achieve the same goal by agreeing with the most innocuously worded alternative. From the standpoint of the interviewer, the answers of such a respondent may appear inconsistent, volatile, and lacking in stability. However, they may be quite consistent from the standpoint of the person who is responding to other aspects of the situation instead of the content of the question. Her responses may be consistent with standards for entertaining a stranger in her home, for example. Nevertheless, such responses reflect a nonattitude toward the object in question. Open-ended questions and probes are clearly indicated by our argument. To discover modes of thinking, one must invoke the reasoning a respondent is using to arrive at his conclusion. To do this, one is better off exploring a small number of issues at length rather than asking a few questions on many issues. Some closed ended techniques are still quite appropriate. Our analysis suggests the importance of filter questions to make sure objects are in a respondent's domain of relevance. There are existing techniques to identify dimensions used in classification that may help in invoking the respondent's filing system. Various forms of sentence frames may be useful in invoking a respondent's grammar of beliefs. The development of such operational measures lies beyond the scope of the present paper.

\section{Ambivalence}

Our model suggests a number of potential sources of ambivalence. We distinguish ambivalence from confusion and disorientation. Ambivalence refers to conflicting valences toward a political object rather 
than to lack of clarity in its meaning. Our model suggests four sources of ambivalence:

1. Ambivalence resulting from multiple classification in the filing system. In our model, the grammar of beliefs is organized around the categories one uses in the filing system. Each category invokes a different set of beliefs from the person's grammar. While we would expect the set of beliefs organized around a single category to be reasonably consistent, there is much less reason to expect that sets of beliefs organized around different categories will be free of contradictions. Thus, multiple classification of objects produces a high likelihood of invoking some contradictory response tendencies.

2. Ambivalence resulting from disagreements among surrogates. If one relies heavily on surrogates to mediate one's attitudes toward political objects, it is not unlikely that one will find them in disagreement on some issues.

3. Ambivalence resulting from contradictions between surrogates and one's grammar of beliefs. One may have a set of beliefs that leads to one set of conclusions about a political object but find that the surrogates one normally uses hold a different view.

4. Ambivalence resulting from using different modes. It is possible that individuals will not restrict themselves to a single mode on an issue but will use more than one. They may find that the dictates of solidarity conflict with their beliefs about how to achieve desired collective goods, for example. Contradictory response tendencies from using different modes is an additional source of ambivalence.

Given these multiple sources of ambivalence, it seems useful to us to assume that ambivalence will be typical of most people's attitudes toward most objects rather than exceptional. Research strategies based on this assumption will look somewhat different from conventional research strategies.

\section{Grounding the Modes in Social Structure}

We have left unanswered such questions as how people acquire the particular mode vector that they employ, how the use of modes is related to socioeconomic status and education, and numerous other valid empirical questions. We have some guesses about these, but they need to be clearly distinguished from hypotheses derived from our argument. As an example of how one might approach such a problem empirically, we will take up the issue of whether people who rely on an ideological mode have a "larger" domain of relevance than others. First, if one asks the question in terms of public objects rather than 
political objects, it's not clear that size is a very meaningful question. A more meaningful question to ask is which objects are included. One might ask, for example, how much of the front page of the New York Times is typically included.

We expect that most news assemblers ${ }^{8}$ rely heavily on an ideological mode. In judging whether given public figures or events are newsworthy, they are likely to ask about the relationship of the object to collective goods. Hence, the domain of relevance of these news assemblers is likely to correspond to that set of news consumers who also employ an ideological mode. Other news assemblers-for example, those who edit a trade association or union paper-may use a different mode in selecting what to report, a solidarity mode, for example. We would hypothesize a correspondence between the mode used by the news assemblers of a particular medium and that used by the consumers of that medium. It is important to recognize that not all public media reflect the mode used by the news editors of the New York Times.

\section{CONCLUSIONS}

Schuman and Johnson (1976) have recently provided a comprehensive review of the literature relating attitudes to behavior. In it, they discuss at some length the classic study by LaPiere (1934), in which motel proprietors accommodated a Chinese couple, even though earlier, in answer to an inquiry, they had refused to make a reservation for this couple. Their closing statement stands equally well as our conclusion:

Leaving aside all the methodological points touched on in earlier pages, the result still puzzles us. Did the proprietors picture Chinese only as laborers in pigtails and coolie hats, and not even recognize the couple before them as Chinese? Perhaps for some the word "Chinese" was like "Wallonians," ... merely a strange-sounding term on which to casually project antipathies, but quite divorced from real people. Or perhaps proprietors acted, as often suggested, in terms of an overriding belief that the less disturbance the better. How shall we find the answers to these and other questions? One good way, not perfect by any means but among the best available, is to ask, and then to listen as well as we can for each proprietor's personal definition of the situation. If we attempt to do this with a concern not merely clinical, but with the goal of representing a meaningful population of proprietors, of proceeding systematically so as to avoid bias in our inquiry, and of gathering information in a form that can be internally analysed and connected to such social categories as age and sex, then we have reinvented the attitude survey in its richest form.

These remarks suggest that standard attitude measurement . . . represents 
perhaps the least interesting contribution of modern attitudinal survey research. Simple pro-con dimensions, even if expanded to include measurement of intensity, centrality, or extremity, only begin to tap the potential worth of the survey interview. Its deeper value lies in its capacity to explore the ideas, beliefs, values, conflicts, and especially frames of reference of large and important populations. When this is done, particularly in an open-eyed and open-ended way, the goal, and occasionally the outcome, is not the prediction of human behavior, but rather a fuller understanding of persons who are not only objects to be observed, but also themselves minds trying to grasp the significance of the human scene in which they perform.

\section{FOOTNOTES}

1. Ann Arbor News, April 17, 1975.

2. This is a good point to acknowledge our general intellectual debt to two papers by Converse $(1964,1970)$. We see the present work as a further elucidation of the nature of belief systems, a task which he began in these essays.

3. Molotch and Lester (1974) have an extremely useful formulation of the social processes. They distinguish among "news promoters - those individuals and their associates (e.g., Nixon, Nixon's secretary; Kunstler, Kunstler's spokesman; a man-who-sawa-flying saucer) who identify (and thus render observable) an occurrence as special, on some ground, for some reason, for others ... news assemblers (newsmen, editors, and rewritemen) who, working from materials provided by the promoters, transform a perceived finite set of promoted occurrences into public events through publication or broadcast... [and] news consumers (e.g., readers) who ... attend to certain occurrences made available as resources by the media and thereby create in their own minds a sense of public time." We are concerned in this paper with the processes employed by news consumers.

4. We were tempted to call this part of a mode a "belief system" but feared that this term seemed as inclusive as "mode." Furthermore, "system" may be misleading because we wish to leave as an empirical question just how closely integrated are the elements of any particular grammar of beliefs.

5. In the interests of promoting nonsexist language, we will arbitrarily alternate the gender of our pronouns where convenient.

6. The economists" concept of collective goods has found its way into sociology and political science mainly through the tremendous influence of Mancur Olson's The Logic of Collective Action (1965). Collective goods can be thought of as desired "system states" and the two terms will be used interchangeably. For some purposes, it is necessary to distinguish among different properties of collective goods-in particular, exclusivity and nonrivalness of supply. Our use here focuses on the first of these properties, defined by Olson as an attribute of a good "such that, if any person $X_{\mathrm{i}}$ in a group $X_{1}, \ldots, X_{i}, \ldots, X_{n}$ consumes it, it cannot feasibly be witheld from the others in that group.

7. The term identification group as used here bears a close relationship to the concept of reference group as discussed by Kelley (1965) and Shibutani (1961). Kelley defines a normative reference group as "a group in which the individual is motivated to gain or maintain acceptance" (p. 211), and thus one which can set standards to which an individual feels motivated to conform. In partial contrast, Shibutani (1961) defines reference group as "any identifiable group whose supposed perspective is used by the actor as a frame of reference in the organization of his perceptual field" (p. 258). This latter definition underscores the notion that an identification group provides its adherents with a point of view on public events. Kelley's definition underscores the equally important notion that if the identification group is also a membership group (as 
is often the case), it will have the leverage to enforce its perspective by threatening to reject nonconformists.

9. See Molotch and Lester (1974).

\section{REFERENCES}

Converse, P. E. The nature of belief systems in mass publics. In D. E. Apter (Ed.), Ideology and discontent. New York: Free Press, 1964.

Converse, P. E. Attitudes and non-attitudes: continuation of a dialogue. In E. R. Tufte (Ed.), The quantiative analysis of social problems. Reading, MA: Addison-Wesley, 1970.

Kelley, H. Two functions of reference groups. In H. Proshansky and B. Seidenberg (Eds.), Basic studies in social psychology. New York: Holt, Rinehart and Winston, 1965.

Lane, R. Patterns of political belief. In J. M. Knutson (Ed.), Handbook of political psychology. San Francisco: Jossey-Bass, 1973.

LaPiere, R. T. Attitudes vs. actions. Social Forces, 1934, 13, 230-237.

Molotch, H., and Lester, M. News as purposive behavior. American Sociological Review, 1974, 39, 101-112.

Olson, M., Jr. The logic of collective action. Cambridge, MA: Harvard University Press, 1965.

Rosenberg, M. J, and Abelson, R. P. An analysis of cognitive balancing. In M. J. Rosenberg, C. J. Hovland, W. J. McGuire, R. P. Abelson, and W. J. Brehm, Attitude Organization and Change. New Haven: Yale University Press, 1960.

Schuman, H., and Johnson, M. P. Attitudes and behavior. In A. Inkeles (Ed.), Annual Review of Sociology: 1976, Palo Alto, Calif.: Annual Reviews Inc., 1976.

Shibutani, T. Society and personality. Englewood Cliffs, NJ: Prentice-Hall, 1961. 